report of an unusual relapsing rhombencephalitis associated with seroconversion to $L$ monocytogenes. ${ }^{5}$ Until recently serological diagnosis has been unreliable because of cross reacting antibodies, but the present assay, only available at the Public Health Laboratory Service (PHLS) in Colindale in the UK, is more accurate and seroconversion is suggestive of disease.

Our patient had severe brain stem involvement but differed from the above descriptions in having myelitis as well. Acute demyelinating encephalomyelitis has not to our knowledge been associated with listerial infection and would be difficult to distinguish from microabscesses by imaging or evoked potentials. Partially treated meningitis and the brain stem encephalitis described in children by Bickerstaff have different clinical features. ${ }^{6}$ Other causes of a lymphocytic encephalitis were excluded.

We recommend that any child with focal brain stem and/or spinal cord signs and a cerebrospinal fluid lymphocytosis, with or without encephalitis, should be treated with high dose intravenous ampicillin and gentamicin until listerial infection has been excluded.

We thank Dr McLauclin, Central PHLS, Colindale Avenue, London for the serological assay.

1 John JF. Listeria monocytogenes. In: Harris AA, ed. Micro bial disease. Handbook of clinical neurology. Amsterdam: bial disease. Handbook of

2 Tim TW, Jackson MA, Shannon K, Cohen B, McCracken GH. Non-neonatal infection due to Listeria monocytogenes. Pediatr Infect Dis 1984;3:213-7.

3 Pollock SS, Pollock TM, Harrison MJG. Infection of the central nervous system by Listeria monocytogenes: a review of 54 adult and juvenile cases $Q \mathcal{F}$ Med 1984;53:331-40.

4 Goday A, Lozano F, Santamaria J, Gallart T, Tolosa E. Transient immunologic defect in a case of listeria rhombencephalitis. Arch Neurol 1987;44:666-7.

5 Zeman A, Bamford JM, Warlow CP, Mitchell RG. Listeria encephalitis with intermittent symptoms and serological diagnosis. F Neurol Neurosurg Psychiatry 1988;51:458-9.

6 Bickerstaff ER Brain stem encephalitis. Further observation on a grave syndrome with a benign prognosis. BMF 1957;i: on a grave

\title{
No sensory neuropathy during pyridoxine treatment in homocystinuria
}

\author{
Willink Biochemical \\ Genetics Unit, \\ Royal Manchester \\ Children's Hospital, \\ Pendlebury, Manchester \\ M27 1HA \\ C Mpofu \\ C Whitehouse \\ B Fowler \\ J E Wraith \\ Department of \\ Neurophysiology, \\ Royal Manchester \\ Children's Hospital \\ S M Alani \\ Correspondence to: \\ DrWraith.
}

Accepted 26 June 1991

(ArchDisChild 1991;66:1081-2)

\section{Mpofu, S M Alani, C Whitehouse, B Fowler, J E Wraith}

\begin{abstract}
Seventeen patients with cystathionine synthase deficiency homocystinuria were examined clinically and neurophysiologically for evidence of sensory neuropathy. All had received high dose pyridoxine (vitamin $\mathrm{B}-6$ ) for many years. Absence of neurological disturbance in all cases suggests long term treatment with pyridoxine in the dosages used in homocystinuric patients is not harmful.
\end{abstract}

Homcystinuria due to cystathionine synthase deficiency, an autosomal recessive disorder of methionine metabolism, results in mental, ocular, skeletal, and vascular disease if untreated. About half of the patients respond to treatment with pharmacological doses of pyridoxine (vitamin B-6). ${ }^{1}$ In our experience unresponsive patients can be managed effectively with a diet low in methionine. We have alsogiven pyridoxine to patients with no clear response to the vitamin on the basis that the exact mechanism of pyridoxine responsiveness is unknown and the assessment of partial responsiveness is difficult. High dose pyridoxine is reported to be associated with sensory neuropathy. ${ }^{2}$ Reports of toxicity in humans on relatively low pharmacological dosages $(200 \mathrm{mg} / \text { day })^{3}$ have alerted us to the possibility of pyridoxine toxicity in patients with homocystinuria.

Seventeen patients with homocystinuria (eight clearly pyridoxine responsive) who had been treated with large doses $(200-600 \mathrm{mg} /$ day $)$ of pyridoxine over many years (10-24 years) were examined clinically and neurophysiologically for evidence of neuropathy.

\section{Patients and methods}

All patients were under the care of the Willink Biochemical Genetics Unit. Sex, age at diagnosis, pyridoxine responsiveness, daily dosage, and duration of treatment are shown in the table.

Inquiry was made about sensory symptoms, including difficulty handling objects, absence of. sensation leading to unnoticed injury, weakness, and problems with balance and walking. Physical examination looked specifically at touch (cotton wool), pain (pin prick), proprioception, Romberg's sign, tendon reflexes, and observation of gait.

Plasma concentrations of pyridoxal phosphate were measured by high performance liquid chromatography. ${ }^{4}$

Electrophysiological studies were performed to look for possible subclinical effects of pyridoxine on the peripheral nerves. A supramaximal stimulation of $0.1 \mathrm{~ms}$ duration was delivered at 1 second intervals, using surface electrodes (ring electrodes for finger stimulation). The median (index finger to wrist) and sural (calf to lateral malleolus) sensory potentials were recorded using surface electrodes. Onset to latency $(\mathrm{ms})$, peak to peak amplitudes $(\mathrm{uV})$, and sensory conduction velocity $(\mathrm{m} / \mathrm{s})$ were measured. The median and lateral popliteal motor responses were recorded over abductor 
Details of 17 patients studied

\begin{tabular}{|c|c|c|c|c|c|c|c|c|}
\hline $\begin{array}{l}\text { Patient } \\
\text { No }\end{array}$ & Sex & $\begin{array}{l}\text { Age at } \\
\text { diagnosis }\end{array}$ & $\begin{array}{l}\text { Response to } \\
\text { pyridoxine }\end{array}$ & $\begin{array}{l}\text { Daily dose } \\
\text { of pyridoxine } \\
\text { (mg) }\end{array}$ & $\begin{array}{l}\text { Duration of } \\
\text { treatment } \\
\text { (years) }\end{array}$ & $\begin{array}{l}\text { Plasma } \\
\text { concentration } \\
\text { pyridoxal } \\
\text { phosphate } \\
\text { (nmol/l) }\end{array}$ & $\begin{array}{l}\text { Motor } \\
\text { conduction } \\
\text { velocity }(N 1) \\
(\mathrm{m} / \mathrm{s})\end{array}$ & $\begin{array}{l}\text { Sensory nerve } \\
\text { conduction }(N 2) \mu V)^{*}\end{array}$ \\
\hline $\begin{array}{l}1 \\
2 \\
3 \\
4 \\
5 \\
6 \\
7 \\
8 \\
9 \\
10 \\
11 \\
12 \\
13 \\
14 \\
15 \\
16 \\
17\end{array}$ & $\begin{array}{l}\mathbf{M} \\
\mathbf{F} \\
\mathbf{F} \\
\mathbf{F} \\
\mathbf{F} \\
\mathbf{M} \\
\mathbf{F} \\
\mathbf{M} \\
\mathbf{F} \\
\mathbf{M} \\
\mathbf{M} \\
\mathbf{M} \\
\mathbf{F} \\
\mathbf{F} \\
\mathbf{F} \\
\mathbf{M} \\
\mathbf{F}\end{array}$ & $\begin{array}{r}13 \text { years } \\
18 \text { years } \\
10 \text { years } \\
19 \text { days } \\
14 \text { days } \\
17 \text { days } \\
12 \text { days } \\
14 \text { days } \\
20 \text { days } \\
30 \text { days } \\
10 \text { days } \\
7 \text { years } \\
10 \text { years } \\
14 \text { years } \\
10 \text { years } \\
7 \text { years } \\
3 \text { years }\end{array}$ & $\begin{array}{l}\text { Yes } \\
\text { Yes } \\
\text { Yes } \\
\text { None } \\
\text { None } \\
\text { Part } \\
\text { None } \\
\text { Part } \\
\text { None } \\
\text { None } \\
\text { None } \\
\text { None } \\
\text { Yes } \\
\text { Yes } \\
\text { Yes } \\
\text { None } \\
\text { Yes }\end{array}$ & $\begin{array}{l}200 \\
200 \\
200 \\
300 \dagger \\
300 \\
400 \\
300 \dagger \\
400 \\
300 \\
450 \\
400 \\
300 \\
500 \\
500 \\
200 \\
400 \\
200\end{array}$ & $\begin{array}{r}7 \\
9 \\
10 \\
11 \\
14 \\
14 \\
15 \\
16 \\
16 \\
18 \\
18 \\
19 \\
20 \\
21 \\
22 \\
22 \\
24\end{array}$ & $\begin{array}{l}1337 \\
1014 \\
882 \\
166 \\
1123 \\
636 \\
29 \\
585 \\
1451 \\
402 \\
618 \\
1352 \\
1390 \\
1347 \\
781 \\
478 \\
1582\end{array}$ & $\begin{array}{l}39 \\
47 \\
44 \\
49 \\
50 \\
52 \\
48 \\
58 \\
51 \\
49 \\
49 \\
39 \\
53 \\
50 \\
51 \\
44 \\
41\end{array}$ & $\begin{array}{l}10 \\
15 \\
10 \\
12 \\
20 \\
10 \\
15 \\
10 \\
10 \\
20 \\
15 \\
10 \\
10 \\
13 \\
15 \\
10 \\
10\end{array}$ \\
\hline
\end{tabular}

*Nerve conduction was also performed in the upper limbs, all results were normal. In this table the results from left lateral popliteal nerve (motor conduction, $\mathrm{N} 1$ ) and the left sural nerve (sensory amplitude, N2) are shown. †Non-compliance.

Normal ranges: pyridoxal phosphate $20-50 \mathrm{nmol} / \mathrm{l}$, motor conduction velocity (NI) $40-56 \mathrm{~m} / \mathrm{s}$, and sensory nerve conduction (N2) $>5 \mu \mathrm{V}$.

pollicus brevis and extensor digitorum brevis respectively after stimulation of the median nerve at wrist and elbow and the lateral popliteal nerve at ankle and fibular head. Distal and proximal latency (ms), compound muscle potential amplitude (negative component, $\mathrm{mV}$ ), and motor conduction velocity $(\mathrm{m} / \mathrm{s})$ were recorded.

\section{Results}

Inquiry indicated no symptoms suggestive of neuropathy in any of the patients and physical examination was normal in all cases. Plasma concentrations of pyridoxine metabolites and the results of electrophysiological studies are shown in the table.

Very high plasma concentrations of pyridoxine and pyridoxal phosphate in most patients confirmed compliance with treatment, at least at the time of study. This indicates adequate uptake of pyridoxine, conversion to pyridoxal phosphate, and maintenance of high concentrations of these compounds. In two patients with much lower concentrations of vitamers poor compliance was confirmed after direct questioning.

Nerve conduction was completely within the normal range for each of the four nerves studied.

\section{Discussion}

Evidence of peripheral neuropathy was first reported in seven adults aged 20-43 years receiving 2-6 g/day of oral pyridoxine for periods of two to 40 months. ${ }^{2}$ In a less detailed study in which some subjects were not clinically examined evidence of neuropathy was reported in 16 subjects receiving $0 \cdot 2-5 \cdot 0 \mathrm{~g}$ of pyridoxine daily, notably in three subjects receiving 200 , 500 , and $500 \mathrm{mg} /$ day respectively, for eight months to three years. ${ }^{3}$ In a review based on a literature survey it was concluded that pyridoxine administration below $500 \mathrm{mg} /$ day appears to be safe, ${ }^{5}$ although this was based on treatment periods of only up to six years and takes no account of intake related to body weight.

In our study daily doses are less than those reported to cause neuropathy. However these doses related to body weight ranged from $10-90 \mathrm{mg} / \mathrm{kg} /$ day during the the first 10 years of life, which is closer to the $25-120 \mathrm{mg} / \mathrm{kg} /$ day (based on assumed body weights) in adults reported by Schaumburg et al. ${ }^{2}$ Also our homocystinuric patients received pyridoxine for 7-24 years (mean 16 years), which is far longer than in previous reports. Therefore the finding of no evidence of neuropathy by extensive clinical and neurophysiological studies is reassuring. This suggests that long term treatment of homocystinuria with doses up to 800 mg of pyridoxine per day is not harmful.

Differences in handling and storage of pyridoxine vitamers between adults and children or in cystathionine synthase deficiency are unlikely. In fact pyridoxal phosphate concentrations in our compliant patients ranged from 8-32 (average 20) fold higher than the upper limit of the control range. This is higher than the 6-7 fold increase of pyridoxal phosphate reported in six healthy adults receiving $100 \mathrm{mg}$ oral pyridoxine/day. ${ }^{6}$ Despite these reassuring results careful thought should be given to the class of homocystinuric patient treated with pyridoxine and the amount prescribed. The justification for giving patients who are unresponsive to pyridoxine large amounts of the vitamin must be questioned. In patients who are responsive to pyridoxine the smallest dosage compatible with good biochemical control (absence of homocystine from plasma) should be recommended.

This work was supported by the Research Trust for Metabolic Disease in Childhood (RTMDC)

1 Mudd SH, Levy HL, Skovby F. Disorders of transsulfuration In: Scriver CR, Beaudet AL, Sly WS, Valle D, eds. The metabolic basis of inherited disease. 6th Ed. New York: Graw-Hill, 1989:693-734.

2 Schaumburg H, Kaplan J, Windebanke A, et al. Sensory neuropathy from pyridoxine abuse. $N$ Engl f Med 1983 309:445-8.

3 Parry GJ, Bredesen DE. Sensory neuropathy with low dose pyridoxine. Neurology 1985;35:1466-8.

Serfontein WJ, Ubbink JB, De Villiers LS, Rapley CH Becker PJ. Plasma pyridoxal-5-phosphate levels as a risk index for coronary artery disease. Atherosclerosis 1985;55: $357-61$.

5 Cohen M, Bendich A. Safety of pyridoxine-a review of human and animal studies. Toxicol Lett 1986;34:129-39.

6 Lumeng $\mathrm{L}$, Lui A, Li T. Plasma content of $\mathrm{B}_{6}$ vitamers and its relationship to hepatic vitamin $\mathrm{B}_{6}$ metabolism. F Clin Invest 1980;66:688-95. 